\title{
The Role of Mediation Morale: The effect of Islamic leadership and emotional intelligence on Employee Performance
}

\author{
"Baharuddin Jumaing ${ }^{1}$, Murdifin Haming ${ }^{2}$, Bahar Sinring ${ }^{3}$, Ibrahim Dani ${ }^{4}$ \\ ${ }^{1}$ (Doctoral Student in Faculty of Economics, Muslim University of Indonesia \\ (Faculty of Education and Teacher Training, Alauddin State Islamic University in Makassar) \\ 2,3,4 (Faculty of Economics, Muslim University of Indonesia) \\ Corresponding Author: Baharuddin Jumaing
}

\begin{abstract}
The approach in this study is an explanatory research that is used to describe the effect of the Islamic leadership and emotional intelligence on morale and performance employees. 91 employees at the Faculty of Faculty of Faculty of Education \& Teacher Training and Faculty of Science \& Technology of the Alauddin State Islamic University of Makassar as a sample. Hypothesis testing is done using SEM (Structural Equation Modeling) with the WaphPLS Ver. 5.0 as research equipment. This study analyzes the influence of Islamic leadership, emotional intelligence on morale and performance of employees. The research proves that the Islamic leadership is a positive and significant effect on employee morale. The low of emotional intelligence cannot provide significant effect on the increase in employee morale. Islamic Leadership can make to improve employee performance. The low of emotional intelligence cannot provide significant effect on employee performance. The high employee morale and demonstrated by employees is now making a positive and significant effect to employee performance. Morale is significantly functioning as a mediating variable in explaining the Islamic leadership effect on employee performance. Pad other parts morale is not able to act as a mediating variable in explaining the effect of emotional intelligence on employee performance
\end{abstract}

Keywords: Islamic leadership, emotional intelligence, morale, employee performance

\section{Introduction}

Higher education has a very strategic position in order to produce quality human resources, for it takes a college readiness with all devices (employees and lecturers). To support the success of the college takes a lot of factors; one of them is the leadership factor. Leadership is a central role in any effort to coaching (management activities). Leadership determines even often the size of the search for the cause's reciprocation of an organization. Today we are entering the era of globalization. The dynamics of an organization to be the leader, superior and advanced, is determined by the leader's ability to manage the organization. To be required human resources quality. The quality of human resources including the quality of moral, spiritual, physical quality intellectual and so as to face the challenges of the future (Rivai et al., 2004).

Alauddin State Islamic University in Makassar, as one of the State Universities continuously working to improve the quality in producing high organizational performance through the Islamic approach. Leadership in Islam is a moral activity and the process of communication between them in a balanced manner that is directed at achieving goals. Thus the Islamic leadership is not just affecting others (subordinate) to want to work to achieve a predetermined goal. But also has a spiritual value, among others based on the Tauhid (submissive to Allah SWT as a servant and caliph), enforcing the law or rules in Islamic values, such as justice, establish communication and cooperation of mutual respect. In addition to leadership spirit and influence on the performance of employees in the organization, but also required an ability that can control and manage themselves as well as the ability to build relationships with others (Marshall-Mies et al., 2000). The ability of the contextual theory is called emotional intelligence (EI) (Goleman, 2000). Some important elements of emotional intelligence, among others, include empathy, express, understand the feelings, anger control, selfreliance, adaptability, preferably, interpersonal problem-solving skills, perseverance, solidarity, friendliness and respectful attitude. This condition showed that not only intellectual superiority (IQ) is required to achieve similar success, but other skills needed to be a leader (Shapiro, 2001: 5).

The process is done to find the right person in the organization is not easy. Organization with not only requires educated human resources, but rather people who have talent. There are psychological factors that underlie the relationship between a person and organization. Psychological factors that affect the ability of a person in the organization is the ability to manage yourself, initiative, optimism, ability to coordinate the inner emotions, as well as the ability to perform a quiet thinking without emotion (Boyatzis, 2001: 12). Based on 
empirical observation was found to be the employee who complained about the leadership that is applied. Employees are not affected for employees excited and make it difficult to perform well. Leadership in an organization is very important. Compliance subordinate to his superiors and affection to his subordinate leaders is determined by the quality of the relationship and communication between them. Leader in mobilizing and directing subordinates should be able to also change their character.

Leadership is applied at Alauddin state Islamic university in Makassar seen much in reference to Western theories (conventional) and has not been widely practiced Islamic leadership. As one of the higher education institutions of Islam, UIN Alauddin Makassar is central to the development of civilization and Islamic science. For those leaders is required to develop Islamic leadership, emotional intelligence in an effort to strengthen the morale and employee performance. Emotional intelligence is the ability to monitor and control their feelings of themselves and others, and use those feelings to guide thought and action, so that emotional intelligence is very needed for successful in work and produce a good performance in the job (Goleman \& Cherniss, 2001). The statement has similarities with a statement explaining that people who have emotional intelligence will be able to face the challenges and make an employee as a man who is responsible, productive, and optimistic in the face and solve problems in the workplace (Patton et al., 2000).

Another problem is the morale and performance is a problem experienced by the management of UIN Alauddin Makassar. Employee's behavior during the quantity and quality of work, timeliness of work that used employee morale is likely to have decreased, so the impact on employee performance. The condition is caused due to the placement of employees not in accordance with the competence and educational background of employees. As staffing background in religious education is placed in finance, lack of balance between work results achieved, both in quality and quantity by providing incentives. As a result, morale is low and the work is still less than the maximum achieved. The attitude and the low commitment work. Employees not understand the duties and responsibilities assigned to him. Clerks lack the initiative in carrying out the task. Cooperation has not been coordinated between one field and another, because communication between the employees has not been implemented as intended. On some occasions there is a discrepancy between the works of the other occupations.

\section{Islamic Leadership}

\section{Literature review}

Spiritual leadership has evolved as a result of the crisis of leadership that causes further deterioration of human values as a result of their ethical malaise and ethical crisis (Tobroni, 2005). The model of spiritual leadership as the solution of the current leadership crisis (Percy, 2003). Leadership or leadership in Arabic is called by the caliph, Imarah, ziamah, and Imamah. Understanding leadership in the Islamic perspective (Nawawi, 1993) divided into two; 1) Islamic spiritual leadership is the ability to carry out orders and leave the ban of Allah SWT, well done jointly or individually, in other words, leadership is the ability to realize all the will of Allah SWT that has notified him by the Mohammed Prophet, 2). Leadership by empirical understanding of the activities carried out by humans in the life of a community in an effort to realize the togetherness (sociality). Based on such understanding, the Islamic leadership can be identified, through; (a). Leadership is always faced with two sides called the first party and other party leaders are those who are led. Number of leaders certainly less than the led, (b) Leadership as the subject of lead containing lead activities, guides, guides show the way, heads and train so that people can work on their own headed. It further explained that the leadership in Islam is a leadership practices the moral values of Islam in managing an organization, such as the nature of the mandate (trustworthy), "is the (justice), shura" (consultation) and others (Tasmara, 1995).

According to Hakim (2007) that the leadership in Islam has several principles including the principle of tauhid, ash-shura (consultation), al-adll (justice), al burriyyah ma'a mas'uliyyah (freedom with responsibility), legal certainty, haq al-ibad guarantee. Islamic leaders who ideally should have criteria as follows: (1) To be honest, (2) to be believed (Amanah), (3) fathonah (Smart), (4) Fair, (5) Wise and have an attitude of responsibility, (6) Open (willing to accept criticism and advice from others). (7) The sincerity. Charitable and act

\section{Emotional intelligence}

Intelligence who first revealed the existence of other than academic intelligence that can affect the success of a person is Gardner. Intelligence is called the Emotional Intelligence or Emotional Intelligence (Goleman, 2000: 51). Emotional intelligence is the ability of individuals to use emotions effectively manages them and affects relationships with others in a positive (Mayer et al., 1999).

There are five main areas that can be used as the basic definition of emotional intelligence that is; (1) the ability to recognize emotions, (2) managing emotions, (3) motivate yourself, (4) recognize the emotions of others, (5) the ability to build relationships with others. Emotional intelligence in it including the ability to control themselves, spur, persevere, and be able to motivate yourself. The skills include the management of 
emotions both positive and negative (Goleman, 2000: 13). The effective use of emotions theory, that the effective use of emotions that will be able to achieve the goal in building productive relationships and achieve job success (Patton, 1998: 3). Emotional intelligence has a positive effect on morale and performance of a person. Emotional intelligence is associated with human resource management systems, for example for training, in this case emotional intelligence can be used as a basis to provide training in particular. Such training can ultimately improve employee performance (Boyatzis et al., 2000). Five basic skills in emotional intelligence (Goleman \& Cherniss, 2001 :), put forward, namely (1) Self awareness, (2) Self management (3) Motivation, (4) Empathy (social awareness), (5) Relationship Management

\section{Morale}

The importance of morale can be seen as a fundamental part of management activities so that something can be addressed to the direction and power of human potential to the cause, turn, raise the level of desire and togetherness in carrying out the task of individuals and organizations. Morale as any willingness feeling that allows a person to work to generate more employment and better (Hariyanti, 2005: 155). Morale is the willingness and sincerity of someone doing his job well and disciplined to achieve maximum performance (Hasibuan 2009: 94).

There are several reasons the importance of morale for the organization or company (Tohardi, 2002: 425), namely; (1) with the high morale of the employees of the work assigned to him or assigned to him will be resolved with less time and more quickly, (2) with high morale, of course, can reduce the rate of absenteeism (truancy) or does not work laziness, (3) with high morale, the organization or company to benefit from a small number of damage, because as we know that the more dissatisfied in the work, the less eager to work, the greater the damage numbers, (4) with high morale, automatically makes workers or employees will feel comfortable (glad) to work, thus the less likely the employee will be moved to work elsewhere, thus meaning high morale will be able to reduce the number of movement of workers or labor turnover, (5) with high morale can also reduce the number of accidents, because employees who have high morale have a tendency to work carefully and thoroughly, so that in accordance with the work procedures in the organization.

The statement explained that employee morale is very important in supporting the achievement of organizational goals. However, the effect of morale to the achievement of organizational goals occurs indirectly. Work performance variables are variables between the two. Measuring the level of performance can be done by first measuring the morale. When employees have low morale, the level of his performance in decreased. But on the contrary increased morale will increase employee loyalty to the organization to remain devoted him to the organization. In other words, employees will not have the intention to move the work. Morale relationship with job performance basically there is a close relationship; it is in accordance with the wishes of employees and the organization, because the employee morale can affect work performance. Thus the employee in performing their duties of loyalty continues to run well, and will also improve work performance.

\section{Employee performance}

An organization, be it public or private, always driven by a group of people who play an active role to achieve the objectives of the organization. The organization's goals would not be achieved if the performances of members or employees are not optimal. Performance is the result of the quality and quantity of work achieved by a person in performing its functions in accordance with the responsibilities given to him (Mangkunegara, 2002: 67). Another view defines performance as the willingness of a person or group of persons to perform an activity, and completed in accordance with the results of their responsibilities as expected. Based on the notions of performance of some of the above opinion, it can be concluded that the performance is the result of both the quality and quantity has been reached servants, in carrying out his duties in accordance with the responsibilities given organization, and his works are adapted to the work that expected the organization, through the criteria or standards applicable performance of employees in the organization (Mulyadi \& Riva, 2009: 532)

Defined performance as something to be achieved, demonstrated achievement and ability. Performance is basically what is done and not done by employees. Employee performance affects how much they contribute to the organization. (Mathis \& Jackson, 2002: 8) further provides performance standard of someone who visits the quantity of output, quality of output, the output time period, attendance at work and cooperative attitude. The performance standards set by the criteria of the job of explaining what-what has been given to the organization done by the employees, therefore the individual's performance in the job criteria to be measured compared with the existing standards and the results must be communicated to all employees.

\section{Methods}

The research approach in this study is an explanatory research that is used to describe the influence of the Islamic leadership and emotional intelligence on morale and performance of employees at 91 Employees the Faculty of Faculty of Faculty of Education \& Teacher Training and Faculty of Science \& Technology of the Alauddin State Islamic University of Makassar as a sample. Hypothesis testing is done using SEM (Structural Equation Modeling) with the WaphPLS Ver. 5.0 as research equipment. 


IV. Results
The results of the Goodness of fit model (Model 1)
Worthy models on WarpPLS can be seen in the P-value for the average path coefficient (APC) and
ARS and the R-squared value Average (ARS) <0, 05 or significant meaning. Additionally Averag
collinearity VIF (AFVIF) as an indicator of multicollinearity should <5. For it can be shown in the follow
table:
\begin{tabular}{|l|l|}
\hline \multicolumn{1}{|c|}{ Table 1. Goodness of fit model (Model 1) } \\
\hline Average path coefficient (APC) & $0.350, \mathrm{P}<0.001$ \\
\hline Average R-squared (ARS) & $0.562, \mathrm{P}<0.001$ \\
\hline Average adjusted R-squared (AARS) & $0.550, \mathrm{P}<0.001$ \\
\hline Average block VIF (AFVIF) & 2.040, acceptable if $<=5$, ideally $<=3.3$ \\
\hline Tenenhaus GoF (GoF) & 0.649, large $>=0.36$ \\
\hline
\end{tabular}

All the components of the measurement met, the APC value, ARS, and AARS with a yield of p-value $<0,001$ and AFVIF 2,040<=3.3. The next steps performed evaluation outer are model three criteria, i.e. the convergent validity, discriminant validity and reliability of composite. Here are the results of data processing:

a) Convergent validity

Convergent validity of the measurement model can be seen from the correlation between the scores of indicators with a score of loading factor criteria. The value of loading factor for each indicator is the greater than 0.70 can be said to be valid. Furthermore, for if the p-value $<0.05$ was considered significant. Loading factor between $0,40-0,70$ should still be considered to be maintained. Subsequently explained also that, with indicator loading $<0.40$ removed from the model. Deletion indicator with loading between 0.40 to 0.70 does if the indicator could increase the AVE and composite reliability above the limit value. The AVE value limit to 0.50 and composite reliability was 0.50 (Sholihin \& Dwi, 2013). Processing results Convergent Validity can be seen in the following table:

Table 2. Results of the combined output loadings and cross-loading (model 1)

\begin{tabular}{|c|c|c|c|c|c|c|}
\hline Measurement & ISLDR & EMSQ & Wrha & Eprf & SE & Value \\
\hline X11 & $(0.866)$ & -0.009 & 0.056 & 0.318 & 0.082 & $<0.001$ \\
\hline X12 & $(0.814)$ & -0.013 & 0.158 & -0.038 & 0.083 & $<0.001$ \\
\hline X13 & $(0.887)$ & -0.003 & 0.050 & -0.005 & 0.081 & $<0.001$ \\
\hline X14 & $(0.869)$ & 0.006 & -0.074 & 0.248 & 0.082 & $<0.001$ \\
\hline X15 & $(0.755)$ & 0.030 & 0.067 & -0.551 & 0.085 & $<0.001$ \\
\hline X16 & $(0.780)$ & -0.009 & -0.267 & -0.050 & 0.084 & $<0.001$ \\
\hline X21 & -0.031 & $(0.574)$ & -0.408 & 0.475 & 0.089 & $<0.001$ \\
\hline X22 & 0.122 & $(0.825)$ & 0.030 & -0.118 & 0.083 & $<0.001$ \\
\hline X23 & 0.011 & $(0.820)$ & 0.246 & -0.276 & 0.083 & $<0.001$ \\
\hline X24 & 0.020 & $(0.837)$ & -0.171 & 0.204 & 0.083 & $<0.001$ \\
\hline X25 & -0.150 & $(0.732)$ & 0.206 & -0.165 & 0.085 & $<0.001$ \\
\hline Y11 & 0.070 & -0.057 & $(0.948)$ & -0.118 & 0.080 & $<0.001$ \\
\hline Y12 & -0.010 & 0.070 & $(0.938)$ & 0.047 & 0.080 & $<0.001$ \\
\hline Y13 & 0.019 & 0.058 & $(0.953)$ & 0.009 & 0.080 & $<0.001$ \\
\hline Y14 & -0.062 & 0.013 & $(0.929)$ & 0.047 & 0.080 & $<0.001$ \\
\hline Y15 & -0.018 & -0.085 & $(0.932)$ & 0.017 & 0.080 & $<0.001$ \\
\hline Y21 & 0.002 & -0.056 & -0.026 & $(0.917)$ & 0.081 & $<0.001$ \\
\hline Y22 & -0.111 & 0.038 & -0.024 & $(0.907)$ & 0.081 & $<0.001$ \\
\hline Y23 & 0.000 & 0.000 & -0.043 & $(0.929)$ & 0.080 & $<0.001$ \\
\hline Y24 & 0.089 & -0.010 & -0.060 & $(0.948)$ & 0.080 & $<0.001$ \\
\hline Y25 & 0.017 & 0.029 & 0.160 & $(0.890)$ & 0.081 & $<0.001$ \\
\hline
\end{tabular}

Based on these results, the Convergent validity to construct an Islamic leadership $\left(\mathrm{X}_{1}\right)$ indicates that the entire measurement meet the standards convergent validity with the values of $>0.70$ and the $p$-value has a $0,001<0,05$, so that these indicators are not issued on the model. Then to the construct of emotional intelligence $\left(\mathrm{X}_{2}\right)$ shows that there is 1 (one) measurement that does not meet that standard, $\left(\mathrm{X}_{21}\right)$ with a value of $0.574<0.70$, so that the measurement should be excluded from the model. Next to construct morale $\left(\mathrm{Y}_{1}\right)$ indicates that the entire measurement meet the standards convergent validity with the values of $>0.70$ and the pvalue has a $0,001<0.05$. Last to construct the employee's performance $\left(\mathrm{Y}_{2}\right)$ also shows the same thing, that all of measurement standards convergent validity with the values of $>0,70$ and the p-value has a $0,001<0,05$, by measurement that does not meet that standard, $\left(\mathrm{X}_{21}\right)$ with a value of $0,574<0.70$, then there is enough reason to take it out of the model. 
b) Composite reliability

A variable that is deemed capable of (reliable) in explaining the data on these variables, the test can be seen on value of the composite reliability and cronbach's alpha of $>0,60$, for it could be shown in the following table:

Table 3. Latent variable coefficients (composite reliability) (model 1)

\begin{tabular}{|l|c|c|c|c|}
\hline \multicolumn{1}{|c|}{ Measurement } & ISLDR & EMSQ & Wrha & Eprf \\
\hline R-Squared & & & 0.414 & 0.709 \\
\hline Adj. R-Squared & & & 0.401 & 0.699 \\
\hline Composite reliab. & 0.930 & 0.873 & 0.974 & 0.964 \\
\hline Cronbach's Alpha & 0.909 & 0.817 & 0.967 & 0.953 \\
\hline Avg. Var. Extrac. & 0.689 & 0.584 & 0.884 & 0.844 \\
\hline Full Collin. VIF & 1.829 & 1.012 & 2.554 & 2.764 \\
\hline Q-Squared & & & 0.416 & 0.707 \\
\hline
\end{tabular}

The value of composite reliability for Islamic Leadership amounted to 0.930>0.60 while for the variable morale for $0.873>0.60$ and the morale of $0,974>0.60$. Then the last employees performance amounted to $0.964>0.60$. Furthermore, to Cronbach's Alpha in the Islamic leadership variable of $0.909>0.60$. Then emotional intelligence $0.817>0.60$. Next on the morale of $0.967>0.60$. The employees performance of $0.953>$ 0.60 .

\section{Goodness of fit model (Model 2)}

Table 4. Goodness of fit model (Model 2)

\begin{tabular}{|l|l|}
\hline \multicolumn{1}{|c|}{ Measurement } & \multicolumn{1}{c|}{ Model 2 } \\
\hline Average path coefficient (APC) & $0.352, \mathrm{P}<0.001$ \\
\hline Average R-squared (ARS) & $0.564, \mathrm{P}<0.001$ \\
\hline Average adjusted R-squared (AARS) & $0.552, \mathrm{P}<0.001$ \\
\hline Average block VIF (AFVIF) & 2.036, acceptable if $<=5$, ideally $<=3.3$ \\
\hline Tenenhaus GoF (GoF) & 0.660, large $>=0.36$ \\
\hline
\end{tabular}

All the components of the measurement met, the value APC, ARS, and AARS with a yield of p-value $<0.001$ and AFVIF $2.0036<=3.3$ and GoF $0.660>0.36$.

a) Convergent Validity

Processing results Validity Convergent can be seen in the following table:

Table 5. Results of the combined output loadings and cross-loading (model 2)

\begin{tabular}{|c|c|c|c|c|c|c|}
\hline Measurement & ISLDR & EMSQ & Wrha & Eprf & SE & Value \\
\hline $\mathrm{X}_{11}$ & $(0.866)$ & -0.006 & 0.052 & 0.322 & 0.082 & $<0.001$ \\
\hline $\mathrm{X}_{12}$ & $(0.814)$ & -0.006 & 0.156 & -0.034 & 0.083 & $<0.001$ \\
\hline $\mathrm{X}_{13}$ & $(0.887)$ & -0.006 & 0.053 & -0.009 & 0.081 & $<0.001$ \\
\hline $\mathrm{X}_{14}$ & $(0.869)$ & 0.005 & -0.074 & 0.248 & 0.082 & $<0.001$ \\
\hline $\mathrm{X}_{15}$ & $(0.755)$ & 0.025 & 0.069 & -0.554 & 0.085 & $<0.001$ \\
\hline $\mathrm{X}_{16}$ & $(0.780)$ & -0.010 & -0.266 & -0.052 & 0.084 & $<0.001$ \\
\hline $\mathrm{X}_{22}$ & 0.117 & $(0.836)$ & -0.042 & -0.034 & 0.083 & $<0.001$ \\
\hline $\mathrm{X}_{23}$ & -0.003 & $(0.872)$ & 0.139 & -0.147 & 0.082 & $<0.001$ \\
\hline $\mathrm{X}_{24}$ & 0.019 & $(0.825)$ & -0.235 & 0.277 & 0.083 & $<0.001$ \\
\hline $\mathrm{X}_{25}$ & -0.151 & $(0.734)$ & 0.147 & -0.098 & 0.085 & $<0.001$ \\
\hline $\mathrm{Y}_{11}$ & 0.071 & -0.060 & $(0.948)$ & -0.129 & 0.080 & $<0.001$ \\
\hline $\mathrm{Y}_{12}$ & -0.008 & 0.063 & $(0.938)$ & 0.046 & 0.080 & $<0.001$ \\
\hline $\mathrm{Y}_{13}$ & 0.020 & 0.055 & $(0.953)$ & 0.011 & 0.080 & $<0.001$ \\
\hline$Y_{14}$ & -0.066 & 0.025 & $(0.929)$ & 0.063 & 0.080 & $<0.001$ \\
\hline$Y_{15}$ & -0.019 & -0.083 & $(0.932)$ & 0.011 & 0.080 & $<0.001$ \\
\hline$Y_{21}$ & 0.005 & -0.066 & -0.012 & $(0.917)$ & 0.081 & $<0.001$ \\
\hline$Y_{22}$ & -0.109 & 0.032 & -0.021 & $(0.907)$ & 0.081 & $<0.001$ \\
\hline$Y_{23}$ & 0.000 & -0.004 & -0.040 & $(0.929)$ & 0.080 & $<0.001$ \\
\hline$Y_{24}$ & 0.087 & -0.002 & -0.065 & $(0.948)$ & 0.080 & $<0.001$ \\
\hline$Y_{25}$ & 0.013 & 0.042 & 0.145 & $(0.890)$ & 0.081 & $<0.001$ \\
\hline & & & & & \\
\hline
\end{tabular}


The convergent validity for the entire construct of Islamic leadership $\left(\mathrm{X}_{1}\right)$, the construct of intelligence emotional (X2), morale $\left(\mathrm{Y}_{1}\right)$ and employee performance $\left(\mathrm{Y}_{2}\right)$ showed that all Convergent Validity of measurement standards with the values of $>0.70$ and $p$-value has a value of $0,001<0,05$.

b) Composite reliability

Table 6. Latent variable coefficients (composite reliability) (model 2)

\begin{tabular}{|l|c|c|c|c|}
\hline \multicolumn{1}{|c|}{ Measurement } & ISLDR & EMSQ & Wrha & Eprf \\
\hline R-Squared & & & 0.426 & 0.702 \\
\hline Adj. R-Squared & & & 0.413 & 0.692 \\
\hline Composite reliab. & 0.930 & 0.890 & 0.974 & 0.964 \\
\hline Cronbach's Alpha & 0.909 & 0.834 & 0.967 & 0.953 \\
\hline Avg. Var. Extrac. & 0.689 & 0.670 & 0.884 & 0.844 \\
\hline Full Collin. VIF & 1.829 & 1.009 & 2.541 & 2.763 \\
\hline Q-Squared & & & 0.427 & 0.699 \\
\hline
\end{tabular}

The value of composite reliability for Islamic Leadership, Emotional Intelligence, morale and performance of employees indicates the number> 0.60. Furthermore, to Cronbach's Alpha on emotional intelligence variables Islamic leadership, morale, and overall employee performance showed values above > 0.60 .

c) Discriminant Validity

Discriminant validity test is evidenced by the results of latent variable output correlations. This output reports the correlation coefficient between the latent variables. The criteria used are the square roots (square roots) average variance extracted (AVE) is a column diagonal bracketed must be higher than the correlation between latent variables in the same column (above or below) (Hasanuddin \& Sjahruddin, 2017).

Table 7. Correlations among l.vs. with sq. rts. of Aves (Model 2)

\begin{tabular}{|c|c|c|c|c|}
\hline Variables & ISLDR & EMSQ & Morale & Eprf \\
\hline ISLDR & $(0.830)$ & 0.047 & 0.606 & 0.648 \\
\hline EMSQ & 0.047 & $(0.818)$ & -0.036 & -0.016 \\
\hline Morale & 0.606 & -0.036 & $(0.940)$ & 0.764 \\
\hline Eprf & 0.648 & -0.016 & 0.764 & $(0.918)$ \\
\hline
\end{tabular}

Based on the above data, the overall variable has met the discriminant validity criteria with a range of values from 0,818 to 0,940 .

d) Hypothesis test

The results of the correlation between the constructs measured by the path coefficients and significance levels were then compared to the hypothesis of the study. The significance level used in this study was 5\%. Here is a hypothesis which is intended to prove the truth of allegations of research consisting of three hypotheses, namely:

$\mathrm{H}_{1}=$ Islamic Leadership is a positive and significant effect on morale.

$\mathrm{H}_{2}=$ Emotional intelligence is a positive and significant effect on morale

$\mathrm{H}_{3}=$ Islamic Leadership is a positive and significant effect employee performance.

$\mathrm{H}_{4}=$ Emotional intelligence is a positive and significant effect on employee performance

$\mathrm{H}_{5}=$ Morale is a positive and significant effect on employee performance

$\mathrm{H}_{6}=$ Islamic Leadership is a positive and significant effect on employees performance as a mediated employee morale

$\mathrm{H}_{7}=$ Emotional intelligence is a positive and significant effect on employees performance as a mediated employee morale

The following is an overview of the research results that have been obtained by processing the data: 
Figure 1. Full Model

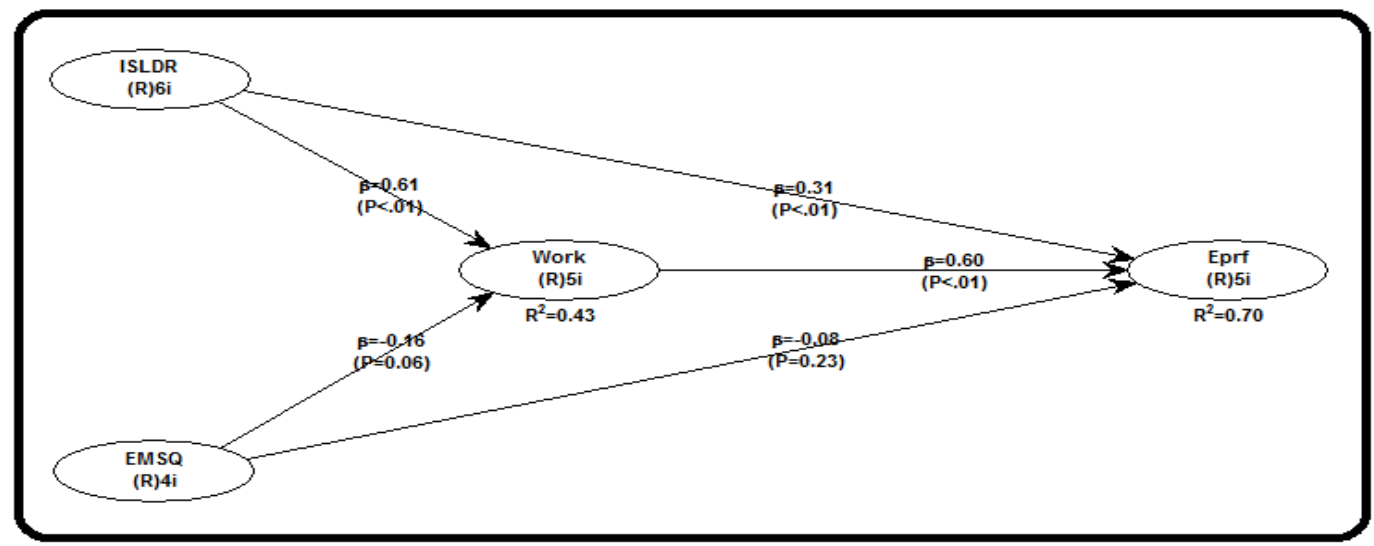

ISLDR : Islamic leadership

EMSQ : emotional intelligence

Work : Morale

Eprf : Employee performance.

The results based on processing the data provide evidence that:

Table 8. Hypothesis Testing

\begin{tabular}{|c|c|c|c|c|c|c|}
\hline \multirow{2}{*}{ Measurement } & \multicolumn{2}{|c|}{ ISLDR } & \multicolumn{2}{c|}{ EMSQ } & \multicolumn{2}{c|}{ Wrha } \\
\cline { 2 - 7 } & path coefficients & P values & path coefficients & P values & path coefficients & P values \\
\hline ISLDR & & & & & & \\
\hline EMSQ & & & & & & \\
\hline Wrha & 0.614 & $<0.001$ & -0.159 & 0.058 & & $<0.001$ \\
\hline Eprf & 0.313 & $<0.001$ & -0.076 & 0.231 & 0.598 & \\
\hline
\end{tabular}

Results output above, explains that among the five (5) direct effects built into our model, there are two of them were insignificant, emotional intelligence and no significant negative effect on morale with the result pvalue $0.058>0.05$ and with the influence emotional intelligence to employee performance results $\mathrm{p}$-value $0.231>0.05$. Thus it can be explained as follows:

1) Islamic Leadership effect on morale

Islamic Leadership is a rational work patterns (unconscious as the Caliph of Allah) and spiritual awareness (conscious as a servant of Allah SWT) (Ishfaq Ahmed, 2014). The influence of Islamic leadership on morale can be evidenced by the results of the path coefficients of 0614 with a negative direction. Path coefficient is positive, meaning that the Islamic leadership is good, resulting in an increase in employee morale, otherwise it can be proved also by the p-value of $0,001<0.05$. The test results prove that the first hypothesis, the Islamic leadership is a positive and significant effect on employee morale. The statement can be interpreted that the Islamic leadership are good, give a significant effect to increase employee morale. This is due to the leadership to do the job is always involve subordinates in decision making so that employees are motivated to improve their morale in the work. Can be explained that leaders can implement a good model of Islamic leadership to be a good example for employees and later became a reason for the increase employee morale is high, these conditions can be seen with the willingness and seriousness of employees to work.

The results of this study supporting the leadership quality theory of leadership qualities that can positively influence the attitudes of followers (morale) and organizational performance supported by the level of satisfaction, motivation, performance, positive energy, and loyalty to the organization. To maintain the Islamic leadership and organizational objectives needs to get support from stakeholders, employees, and at the same time fully comply with the teachings and principles of Islam (Hassan et al., 2011). Supports the findings of other researchers, that the Islamic Leadership related positively and significantly with morale and organizational performance (Majeed et al., 2011)

2) Emotional intelligence on morale

Emotional intelligence is the ability to use emotions effectively manages themselves and affect relationships with people another positively (Mayer et al., 1999). The influence of emotional intelligence on morale can be evidenced by the value of the path coefficients of -0159 with a negative direction. Path coefficients are negative, meaning that an employee-owned emotional intelligence is low, but it can be proved 
also by the results of p-value $0.058>0.05$. The test results prove that the second hypothesis, emotional intelligence and significant negative effect on employee morale. The statement can be interpreted that low emotional intelligence does not give a significant effect on the increase in employee morale. The low ability of employees to always be flexible in their work so that employees have limitations in facing and dealing with adversity or perceived workload of other employees. The results of this study rejected the findings of Boyatzis et al. (2000) that emotional intelligence has a positive effect on morale and performance of a person. Rejecting the findings of Chin et al. (2011) that emotional intelligence is the source of human energy, information and connections within the organization.

\section{3) Islamic Leadership on employee performance}

The leadership qualities of Islam consists of four main attributes; true (al-sidq), trustworthy (amanah), intelligent (fathonah) and convey or seliberation (tabligh). Legitimacy led leaders to be shown on the internalization of the core values of Islam and the values related tasks so that helped shape the personality, leadership and ability. The higher the rate of internalization, the higher the legitimacy of the leader. The higher the legitimacy of the leader, the higher the ability of subordinates to show the work of a more optimal (Mohd Ezani et al., 2011). The effect of Islamic leadership on employee performance can be evidenced by the results of the path coefficients of 0.313.Influence coefficient is positive, meaning that the Islamic leadership is good, resulting in an increase in employee performance, but it can be proved also by the results of p-value $0001<0.05$.

The test results prove that the third hypothesis, the Islamic leadership and significant positive effect on employee performance. The statement can be interpreted that the Islamic leadership is good and indicated by the current leader significant effect (significant) to increase employee performance. This is because although the selection of leaders at be some faculty within the scope of UIN Alauddin Makassar yet fully in the underlying on aspects of true leadership (al-sidq), trustworthy (amanah), intelligent (fathonah) and convey or seliberation (tabliqh) but in the context of the creation of employee performance, Islamic leadership practices demonstrated leaders such as the mandate has been shown properly, that the Islamic leadership practices at UIN Alauddin which is well demonstrated by a leader who can be trusted and run leadership in ways that really so with the use of fees in accordance with the provisions of and regulations, the employee can finish the job properly.

The higher the level of internalization, the higher the legitimacy of the leader. The higher the legitimacy of the leader, the greater the expected sustainability of the organization (goal achievement) (Hassan et al., 2011). Islamic leadership qualities as a tool in helping organizations to continue to interact with stakeholders establish new partnerships and identify future opportunities and develop the ability to improve the performance of the organization (David et al., 2014). Morality based leadership approach to the morality of Nabi Muhammad SAW provides practical examples of virtue and behavior if imitated by the CEO, to assist staff with the potential to sincerely work for the achievement of organizational goals (Beekun \& Westerman, 2012).

4) Emotional intelligence on employee performance

Emotional intelligence is the ability of the individual to feel emotions, accept and build emotions well, understand emotions and emotional knowledge so as to improve the development of emotion (Mayer et al., 1999). The influence of emotional intelligence on the performance of employees can be proven with the value path coefficients of -0076. Path coefficients are negative, meaning that a low emotional intelligence resulted in a decrease in employee performance toward the high, but it can be proved also by the results of the p-value of $0.231>0.05$. The test results prove that the fourth hypothesis, emotional intelligence is a negative and no significant effect on employee performance at UIN Alauddin Makassar.

The statement can be interpreted that low emotional intelligence cannot provide significant effect on employee performance improvement. Demands of the job given to an employee to uphold the mandate consistently (constancy), accompanied by a caring attitude towards peers in implementation is low. The low ability of employees to communicate in ways that mannered and is unable to improve the ability of employees to complete the job that vary (a lot) and the poor quality of work arising from the settlement of employee work performed. The results of this study rejects partially proposed statement Primitive (1999: 64), that emotional intelligence is the ability in the field of emotion that is the ability to face frustration, the ability to control emotions, the spirit of optimism and the ability to establish relationships with others or empathy. Rejecting the findings Ali et al. (2013) that emotional intelligence (EQ) effect on the performance of personnel.

\section{5) Morale on employee performance}

As a driving force organization Employees are required to work with more vigor to be able to face the competition, and to maintain the existence of the organization. Organizations not only expect an employee who is able, capable and skilled, but more important is that they are willing to work hard and willing to achieve optimal results. Abilities, aptitudes, and skills of employees are nothing to the organization with if they do not want to work hard to use the abilities, skills, and the skills they have (Hasibuan, 1999). Morale influence on 
employee performance can be evidenced by the values of path coefficients for 0598. Path coefficients is positive, meaning that employee morale is high, resulting in an increase in the performance of employees toward the high, but it can be proved also by the results of the p-value of $0.001<0.05$. The fifth hypothesis testing results prove that, morale positive and significant impact on employee performance.

The statement can be interpreted that the high employee morale and demonstrated by employees is now making a positive impact and significant (meaningful) to employee performance. This is due to the placement of employees in the work in accordance with the competence, work experience and educational background which is owned and efforts of employees who constantly strive to create and maintain conditions and working environment that is highly conducive to trigger higher employee morale so that the real impact on the ability of employees to use fee amounts are adjusted by the University's capacity. Compensation received by employees in the form of salaries, incentives and salaries committee deemed sufficient to bring their enthusiasm in work so that they always work seriously subsequently leading to the lack of jobs unattended. Employee greatly assisted by the additional compensation in the form of salaries committees so that they have a high spirit in work that resulted in the exact completion time employee. Supports the findings of previous research that high morale proven to improve employee performance (Karsini et al., 2016; Syahropi, 2016).

6) Islamic Leadership on employee performance as a mediated morale

Pattern Islamic leadership approach is self Rasulullah Muhammad SAW mandate holder (leader) in the context of Islamic leadership should emulate the leadership values that have been exemplified by the Prophet. God insists that the practice of Islamic leadership will bring happiness in this world and in the hereafter (Surah Al-Ahzab, 21). Based on the results of testing the effect of indirect (mediation), Sobel test using Preacher Tool and the results are shown as follows:

Table 9. Testing the hypothesis indirect effect (mediation)

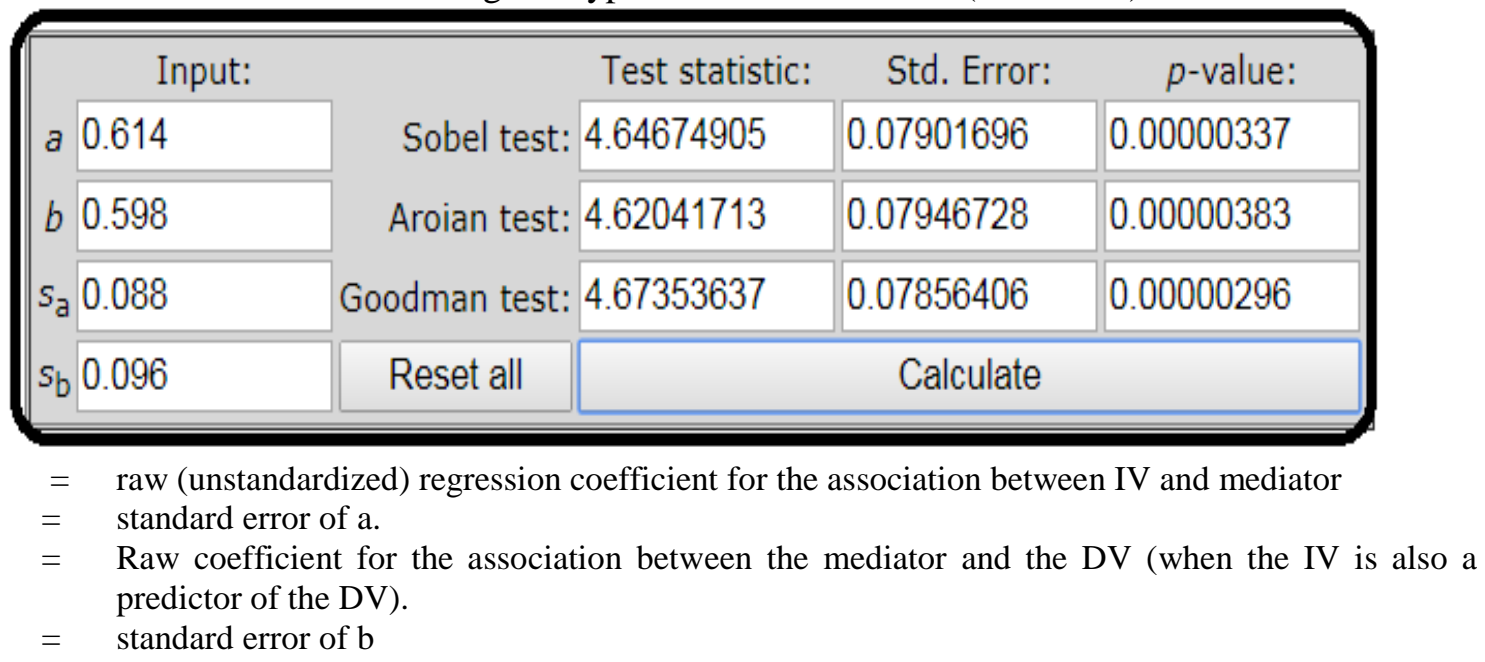

The table explains that the raw (unstandardized) regression coefficient for the association between IV and mediator $=0.614$, the value of the standard error of $\mathrm{a}=0.088$, and the raw coefficient for the association between the mediator and the DV (when the IV IS ALSO a predictor of the DV) $=0598$, next the standard error of $b=0.096$. Sobel Based on these tests, then the value of Sobel test $=4.647$ with the standard error of 0.079 and the p-value $=0.000<0.05$. Under these conditions the hypothesis to six of the Islamic Leadership positive and significant impact on the performance of employees in mediation morale, proved to be supported by empirical facts significantly Morale serves as a mediating variable in explaining the Islamic leadership influence on employee performance.

7) Emotional intelligence on employees performance as a mediated morale

Emotional intelligence is the ability to use emotions effectively manages themselves and affect relationships with others in a positive (Mayer et al., 1999). 
Table 10. Hypothesis testing the effect of indirect (mediation)

\begin{tabular}{|c|c|c|c|c|}
\hline Input: & & Test statistic: & Std. Error: & $p$-value: \\
\hline a -0.159 & Sobel test: & -1.54060438 & 0.06171734 & 0.1234131 \\
\hline$b 0.598$ & Aroian test: & -1.52229834 & 0.0624595 & 0.12793434 \\
\hline$s_{\mathrm{a}} 0.100$ & Goodman test: & -1.55958712 & 0.06096614 & 0.11885748 \\
\hline$s_{\mathrm{b}} 0.096$ & Reset all & & Calculate & \\
\hline
\end{tabular}

Under these conditions, the seventh hypothesis that emotional intelligence is a significant negative effect on the performance of employees in mediation morale. Morale is not able to act as a mediating variable in explaining the effect of emotional intelligence on employee performance.

\section{Conclusion}

Islamic Leadership is a positive and significant effect on employee morale, that the leadership of his job always involves subordinates in decision making so that employees are motivated to improve their morale in the work. Low emotional intelligence cannot provide significant effect on the increase in employee morale. The low ability of employees to always be flexible in their work so that employees have limitations in facing and dealing with adversity or perceived workload of other employees.

Islamic Leadership proven to improve employee performance, that Islamic leadership practices at UIN Alauddin which is well demonstrated by a leader who can be trusted leadership in ways that really so with the use of fees in accordance with the rules and regulations, the employee can complete the work well. Low emotional intelligence cannot provide significant effect on employee performance improvement. Demands of the job given to an employee to uphold the mandate consistently, accompanied by a caring attitude towards peers in implementation is low. The low ability of employees to communicate in ways that mannered and is unable to improve the ability of employees to complete the job that vary (a lot).

High employee morale and demonstrated by employees is now making a positive and significant effect on employee performance. This is due to the placement of employees in the work in accordance with the competence, work experience and educational background which is owned and efforts of employees who constantly strive to create and maintain conditions and working environment that is highly conducive to trigger higher employee morale so that the real impact on the ability of employees to use fee amounts are adjusted by the University's capacity. Morale is significantly functioning as a mediating variable in explaining the Islamic leadership influence on employee performance. Pad other parts morale is not able to act as a mediating variable in explaining the effect of emotional intelligence on employee performance.

\section{Journal Papers:}

\section{References}

[1] Ali, JH, Bemby, B., \& Sentosa, I. (2013). The intelligence, emotional, spiritual quotients and quality of managers. Global Journal of Management And Business Research, 13 (3).

[2] Beekun, RI, \& Westerman, JW (2012). Spirituality and national culture as antecedents to ethical decision-making: a comparison between the United States and Norway. Journal of business ethics, 110 (1), 33-44.

[3] Boyatzis, RE (2001). How and why individuals are Able to develop emotional intelligence. The emotionally intelligent workplace: How to select for, measure, and improve emotional intelligence in individuals, groups, and organisasi, 1, 234-253.

[4] Boyatzis, RE, Goleman, D., \& Rhee, K. (2000). Clustering competence in emotional intelligence: Insights from the Emotional Competence Inventory (ECI). Handbook of emotional intelligence, 99 (6), 343-362.

[5] Chin, STS, Anantharaman, RN, and Tong, Dyk (2011). The roles of emotional intelligence and spiritual intelligence at the workplace. Journal of Human Resources Management Research, 2011, b1-9.

[6] David, WNW, Rahim, MA, \& Nasurdin, AM (2014). Quality of Islamic Leadership and Organizational Performance within the Takaful Industry in Malaysia: A Conceptual Study. Asian Social Science, 10 (21), 135.

[7] Goleman, D. (2000). Leadership that gets results. Harvard business review, 78 (2), 4-17.

[8] Goleman, D., \& Cherniss, C. (2001). The emotionally intelligent workplace: How to select for, measure, and improve emotional intelligence in individuals, groups, and organisasi. Jossey-Bass.

[9] Hakim, Abdul. (2007). Islamic leadership : Mold 1 Semarang ISBN 978-979-3246-95-6. Semarang. Unissula Press

[10] Haryanti, Endang. (2005). Analysis of Effect of Leadership Style and Organizational Climate on Job Satisfaction and Employee Performance Gayamsari District Semarang City Government Offices, Post Graduate Thesis Management Master Program Diponegoro University (unpublished)

[11] Hassan, MEM, Mohammed, N., Abdullah, NA, \& Adham, KA (2011 ). Islamic values, leadership legitimacy and organizational sustainability. International Journal of Economics, Management and Accounting, 19 (2), 169.

[12] Hasanuddin, R., \& Sjahruddin, H. (2017). The Structure of Emotional Intelligence, Spiritual Intelligence and Its Relationship with Work Enthusiasm and Auditor Performance. World Journal of Business and Management, 3 (1), 67.

[13] Hasibuan, Malay SP (2009). Management: The Basics, Understanding, and Problems. Revised Edition. Jakarta: Earth Literacy 
[14] Karsini, K., Paramita, PD, \& Minarsih, MM (2016). Effect of morale and discipline of work on job satisfaction which impact the performance of civil servants and the financial management of local assets (dpkad) Semarang. Journal of Management, 2 (2).

[15] Majeed, Y., Khalid, Z., \& Khan, MA (2011). The impact of leadership on organizational Islamic Objectives. Far East Journal of Marketing and Management, 1 (5), 54-65.

[16] Mangkunagara, Anwar Prabu. (2002), Human Resource Management, PT. Remaja Rosda Karya, Bandung.

[17] Marshall-Mies, JC, Fleishman, EA, Martin, JA, Zaccaro, SJ, Baughman, WA, \& McGee, ML (2000). Development and evaluation of cognitive and metacognitive measures for predicting leadership potential. The Leadership Quarterly, 11 (1), 135-153.

[18] Mayer, JD, Caruso, DR, \& Salovey, P. (1999). Emotional intelligence meets traditional standards for an intelligence. Intelligence, 27 (4), 267-298

[19] Mulyadi \& Rival (2009). Human Resource Management, Jakarta mold ninth.

[20] Nawawi, Hadari. (1993). According to the Islamic leadership. Yogyakarta: Gadjah Mada University Press.

[21] Patton, G., Glover, S., Bond, L., Butler, H., Godfrey, C., \& Di Pietro, G. (2000). The Gatehouse Project: A systematic approach to mental health promotion in secondary schools. Australian and New Zealand Journal of Psychiatry, 34, 586-593.

[22] Percy, M. (2003). A Place at the High Table? Assessing the Future of Charismatic Christianity (Vol. 104). Aldershot: Ashgate.

[23] Purba, Ahmad. (1999). Emotional Intelligence, Series Ayah Bunda, 26 July to 8 August, Dian Raya, Jakarta

[24] Rival, Veithzal. (2004). Leadership and OrganizationalBehavior, 2nd Edition, Jakarta, Rajawali Pers.

[25] Rival. (2004). Human Resource Management for Companies (from theory to practice). King Grafindo Persada, Jakarta.

[26] Shapiro, DL (2008). Revisiting the link between intelligence and transformational leadership leaders'emotional: the moderating role of emotional intensity. in academy of management proceedings. Vol. 2008, No. 1, 1-6

[27] Sholihin, M., \& Dwi, R. (2013). SEM-PLS with WarpPLS 3.0. Andi. Yogyakarta.

[28] Syahropi, I. (2016). Morale influence on the performance of employees of PT. Bangkinang in Pekanbaru (case study on permanent employees pt. Bangkinang). Jom FISIP Volume 3 No.October

[29] Tasmara,Toto. "Personal Muslum Islamic Work Ethic." (1995). PT. Dana Dana Yasa Prima Bhakti. Jakarta

[30] Tobroni. (2005). The Spiritual Leadership. Malang: UMM Press.

[31] Tohardi, A. (2002). Practical Understanding of Human Resources. Bandung: Mandar Maju. 